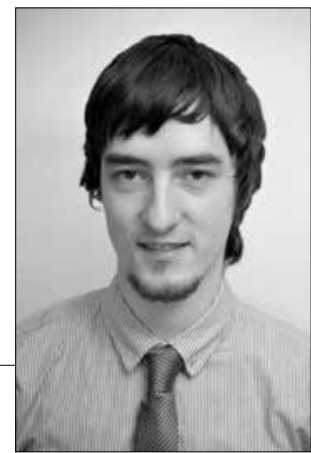

\title{
ŠV. BENEDIKTO IKONOGRAFIJA LIETUVOS ALTORINIUOSE ATVAIZDUOSE
}

\author{
The Iconography of St. Benedict in Lithuanian Altarpieces
}

\begin{abstract}
SUMMARY
This article analyzes the iconography of St. Benedict in Lithuanian altarpieces of 17-19 ${ }^{\text {th }}$ century. The most numerous and valuable pictures belong to the $18^{\text {th }}$ century. They depict the Saint's appearance, his death, apotheoses and heavenly triumph. Since the $17^{\text {th }}$ century, St. Benedict was mostly represented as old bearded patriarch dressed in the black habit with miter on his head and the book of Regula in his hands. Other kind of pictures show his miracles and mystical visions.
\end{abstract}

\section{SANTRAUKA}

Straipsnis skirtas Lietuvos altorinių šv. Benedikto atvaizdų, datuojamų XVII-XIX a., ikonografinėms ypatybėms atskleisti. Gausiausią ir ryškiausią kūrinių dalį sudaro XVIII a. darbai, atspindintys populiariausias to meto Europoje vizijos, mirties ir apoteozès temas. Lietuvoje nuo XVII a. įsitvirtino seno barzdoto benediktinų patriarcho tipažas. Viena atributų grupė akcentuoja šventojo priklausomybę benediktinams (juodas abitas) ir abatystę (pastoralas, mitra, pektoralas, kapa), Regulos autoriaus ir vienuolijos įkūrèjo statusą (knyga, bažnyčios pastatas). Kita reprezentuoja jo gyvenimo stebuklus (taurè su gyvate, įskilęs indas, duona su gyvate ar varnu) ir mistinę viziją (ugninis rutulys).

$\coprod_{\text {ietuvos Didžiojoje Kunigaikštijoje }}$ moteru benediktinu vienuolynai, trys vyru ir trys moteru veikè dabartinèje Lietuvos teritorijoje. Gausiausią ir reikšmingiausią šv. Benedikto atvaizdų dali juose sudare tituliniai altoriniai, gerbi- mui skirti kūriniai. Išlikę šio tipo kūriniai sudaro meniniu ir ikonografiniu požiūriu įdomiausią šv. Benedikto atvaizdu dali Lietuvoje. Nors beveik visi i tyrimą itraukti objektai jau yra žinomi menotyros diskurse ir aptarti bendresnio pobūdžio publikacijose, atskiroms bažny- 
čioms ar kitokioms temoms skirtuose straipsniuose, vis dèlto kaip atvaizdu grupè, siejama vieno šventojo asmens, iki šiol detaliai ikonografiniu aspektu neanalizuota. Tokio pobūdžio tyrimas šiandien tebèra aktualus ir gali praplèsti turimas žinias, pateikti nauju su grupe susijusiu interpretacijų.

Pirmasis benediktinu vienuolynas lietuvių žemėse ikurtas dar XV a. pr., tačiau seniausi atvaizdai šiandien datuojami pora šimtmečių vèliau. Todèl tyrimo anksčiausia chronologinè riba brèžiama XVII a., o vèliausia - XIX a., kai buvo sukurtas paskutinis senosios dailès altorinis šventojo atvaizdas. Šio tyrimo tikslas atskleisti Lietuvoje išlikusių altoriniu šv. Benedikto atvaizdu ikonografines ypatybes išryškinant bendrumus bei specifiškus bruožus Europos kontekste.

\section{ŠV. BENEDIKTAS MARIJINIUOSE XVII A. ALTORIUOSE}

Per visus benediktinu gyvavimo Lietuvoje metus XVII a. pasižymi igyvendintu fundacijų gausa. Tuomet buvo isteigti devyni vienuolynai. Šiuo laiku datuojami seniausieji dokumentiškai užfiksuoti ir mūsų dienas pasiekę šv. Benediktą perteikiantys kūriniai. Nekyla abejonių dèl šv. Benedikto altorinių atvaizdų buvimo visose to amžiaus benediktinu šventovėse, tačiau iš ju iki šiandienos išliko vos pora.

Kražių benediktinių Švč. M. Marijos Nekaltojo Prasidejimo bažnyčios Didžiajame altoriuje yra titulinis paveikslas, kuriame šventieji Benediktas ir Skolastika garbina Nekaltai Pradètają Švč. M. Mariją ${ }^{1}$. Pirmojoje benediktinių bažnyčioje, pastatytoje $1642 \mathrm{~m}$., paveikslas kabejo šoniniame altoriuje. Kitas atvaizdas, išreikštas skulptūrine forma, šiandien randamas Ariogalos šv. arkangelo Mykolo bažnyčios Didžiojo altoriaus sparne ${ }^{2}$. Altorius tarpukariu buvo perkeltas iš 1938-1940 m. pertvarkomos Kauno šv. Mikalojaus benediktiniu bažnyčios ${ }^{3}$. Irenginio pirmame tarpsnyje nuo XVII a. kabėjo Dievo Motinos paveikslas, antrame pagal pirmini sprendimą - Apreiškimo siužeto kūrinys. Taigi šiuos Kražių ir Kauno šv. Benedikto atvaizdus sieja gražus ryšys. Abu kūriniai pasitelkti marijinès temos altoriuose.

Žvelgiant i Kražių paveikslą, jame užfiksuotas Šventojo pokalbio scenoms būdingas kompozicinis išsidèstymas. Abipus Švč. M. Marijos suklupę šventieji vizualiai išreiškia garbinimo veiksmą. Šv. Benediktas vilki juodu vienuolijos abitu ir, be šio iprasto drabužio, jo pečius dar gaubia puošni kapa, kuri panaudota tik Kražiuose ir suteikia kūrinio ikonografijai išskirtinumo. Vakarų dailëje kapa šv. Benedikto ikonografijoje pritaikyta Vèlyvaisiais viduramžiais, populiari ir renesansiniuose darbuose ${ }^{4}$. Vèliau tapo iprasta vienuoli vaizduoti vilkint vien abitą. Kražių paveiksle vienuolyno abato titulą leidžia atpažinti šalia ant žemès pastatyta brangakmeniais ir perlais išdabinta mitra. XVIII a. II pusëje paveikslui pritaisius aptaisus, abato titulas buvo sustiprintas dar ir pastoralu. Tokiu, daugeliui šventojo atvaizdu būdingu atributų komponavimu bylojama apie abato pareigu atsisakymą. Ant žemès padèta atversta knyga - seniausias šventojo atvaizdų atributas, pažymintis ir sureikšminantis parašytos vienuolinio gyveni- 
mo Regulos autorystę $e^{5}$ Iprastai atverstoje knygoje būdavo paliekami i̇rašai apie Benediktą arba citatos iš Regulos: Regula sancti Benedicti; Ego sum Benedictus abbas; Ausculta, o fili, praecepta magistri; Passionibus Christi per patientiam participemur; Disciplinam patris audite; Clamat nobis scriptum, fratres, dicens, qui se exaltat humiliabitur ir t. t. ${ }^{6}$ Kražiu paveikslo pirminiame variante knyga buvo tuščia, tačiau šiandien joje matyti $1910 \mathrm{~m}$. ir 2007 m. palikti su turiniu nesusiję ìrašai apie atliktus restauravimo darbus.

Šv. Benediktas drobejje vaizduojamas senyvo amžiaus, su ilga žila, ị dvi dalis perskirta barzda bei vešliais pusilgiais, ant ausų lipančiais plaukais. Seno benediktinų patriarcho ivvaizdis sukurtas tik XIV a. Italijoje, kai šv. Benediktą šitaip èmè traktuoti naujai ikurtos vienuolijos ${ }^{7}$. Iki tol benediktinai, savo îkūrèją matę jauno ar vidutinio amžiaus, kaip energingą lyderi, pamažu perèmè reformuotą ịvaizdị. Tipažo vizualinę išraišką lèmè Giotto di Bondone sukurtas naujoviškas atvaizdas, kuri èmè kartoti dailininku sekę vèlesnių kartų meistrai ${ }^{8}$.

Kitokiai vaizdavimo krypčiai atstovauja Kauno benediktinems sukurta skulptūra, vienintelè Lietuvoje sekanti bebarzdžio vienuolio vaizdavimo tradicija. Frontalios ir statiškos skulptūros išvaizda ligšioliniuose tyrimuose aprašoma skirtingai: vienu atveju teigiama, kad realistiškai traktuotas „kresnas apskritagalvis šv. Benediktas panašus i sotú, savimi patenkintą žmogų“9, kitu ¡zžvelgiamas oponuojantis emocinis krūvis: „šventasis yra užmerktomis akimis, ramybès būsenoje paniręs į apmąstymus, jo veide žaidžia švelni šypsena"10.

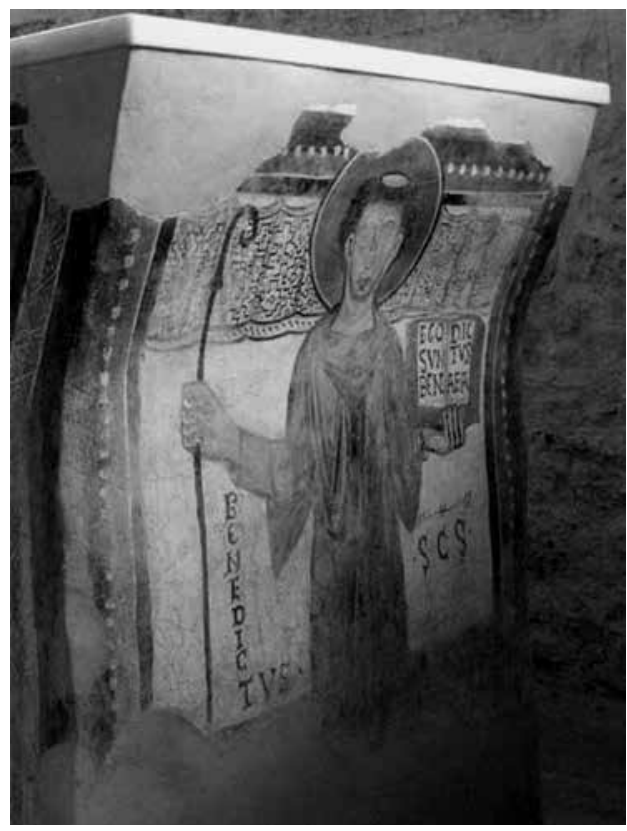

1 il. Nežinomas dailininkas. $\check{S} v$. Benediktas. XI a. Civate San Benedetto al Monte bažnyčia. Italija

Seniausi bebarzdžio šv. Benedikto atvaizdai, datuojami XI a., išlikę Italijoje San Sebastiano al Palatino ir Civate San Benedetto al Monte bažnyčiose ${ }^{11}$. Juose kartojasi frontaliai stovinčio jauno ar vidutinio amžiaus, rudaplaukio, tonzūruoto vienuolio tipažas. Civate bažnyčios freskoje (1 il.) jau atsiradęs pastoralo atributas, kuris šventojo ikonografijoje pirmą kartą pritaikytas dar X a. Otonų laikų miniatūrose norint pabrèžti kilnias abato pareigas $^{12}$. Bebarzdžio vidutinio amžiaus vyro tipažas ị šiaurę nuo Alpių išliko iki baro$\mathrm{ko}^{13}$. Vieną iš daugelio tokios struktūros atvaizdų altoriaus poliptikui sukūrè austrų meistras Thomas Artula, turëjęs dirbtuves Filacho mieste (2 il.). Šio atvaizdo tipas ir atributai atspindi XV a. šiaurietišką šventojo atvaizdu standarta, kuriam itin dažnai pasitelktas taurès su joje esančia viena ar keliomis gyvatèmis motyvas. 


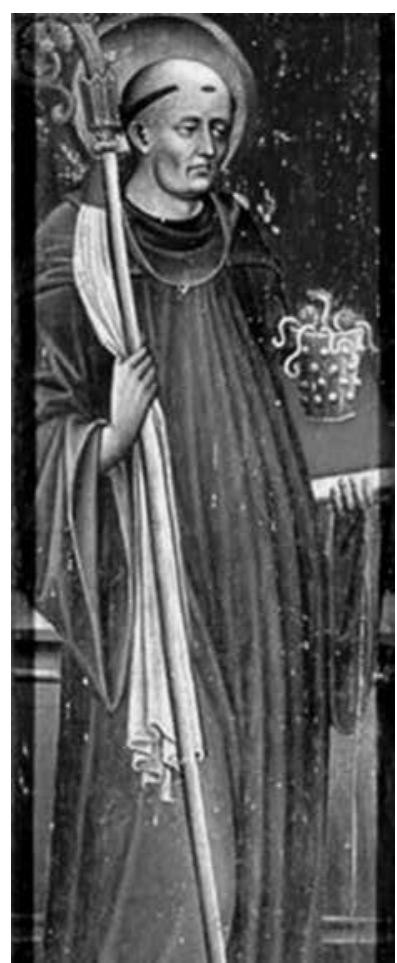

2 il. Thomas Artula. Šv. Benediktas. 1460-1470. Lenta, tempera. Landesmuseum Kärnten. Austrija

Analogiškai pirmavaizdžiams Kauno skulptūra dešinèje rankoje laiko pastoralą kairèje - užverstą regulos knygą ir ant jos uždètą taurę ${ }^{14}$. Naujasis atributas siejamas su sąmokslo išaiškinimo stebuklu, vaizdžiai aprašytu šv. Grigaliaus Didžiojo. Popiežius pasakoja, kad kuri laiką atsiskyrèlio oloje gyvenęs Benediktas buvo prikalbintas pirmą kartą imtis vadovauti vietos atsiskyrèliu bendruomenei. Naujasis tèvas, kitaip nei bendruo- menės gyventa iki tol, stengèsi skatinti ją uoliai laikytis regulos. Po kurio laiko nepatenkintieji susitare jam atimti gyvybę, tačiau niekšingus kẻslus Benediktas stebuklingai atskleidè. Eilinių pietų metu padavus indą su vynu iprastiniam palaiminimui kryžiaus ženklu, šis „suskilo, tarsi būtų sudaužytas ar tarsi i tą mirties indą vietoj kryžiaus būtų kas akmeniu tvojęs ${ }^{\prime 15}$, ir šitaip Benediktas suprato apie nuodus. Po ivvykio vyresnysis bendruomenę paliko.

Apibendrinant galima teigti, kad Kražių ir Kauno kūriniai atstovauja dèl skirtingu regionu itakos suformuotai šv. Benedikto tipažo traktuotei. Kaune buvusi skulptūra, nors sukurta XVII a. II pusėje, atstovauja šiaurietiškai, ikibarokinei tradicijai. Tai vienintelis bebarzdžio šv. Benedikto atvaizdas Lietuvoje, formaliu figūros traktavimu bei laikomu pastoralo ir taurès ant knygos atributu konfigūracija atitinkantis šiaurinių alpių regione $\mathrm{XV}$ a. vyravusią ikonografiją. $\mathrm{O}$ Kražiams nutapytas paveikslas siejasi su itališkaisiais pavyzdžiais ir yra ankstyvas barokišku vizijinio pobūdžio atvaizdų reprezentantas. Jam pasitelktas Šventojo pokalbio kompozicinis principas ir ikonografija. Šv. Benediktas perteiktas su viduramžiu ir renesanso atvaizdams būdingu atributu - kapa, taip pat su iprastai šalia pastatyta mitra ir atversta Regulos knyga - seniausiu šventojo ikonografijos atributu.

\section{VIZIJA, MIRTIS IR APOTEOZE் XVIII A. ŠV. BENEDIKTO ATVAIZDUOSE}

Atnaujinant kai kurių benediktinu šventoves XVIII a., senuosius atvaizdus imta keisti naujos estetikos kūriniais.
1753-1759 m. rekonstruojamame Vilniaus šv. Kotrynos bažnyčios interjere vietoje buvusių devynių, irengti nauji altoriai, 
tarp kurių vienas skirtas šv. Benediktui. Senojo altoriaus titulinis kūrinys, minètas $1746 \mathrm{~m}$. vizitacijoje ${ }^{16}$, buvo perkeltas i Dievo apvaizdos koplyčia, kur 1804 m. ivardintas kaip senas, ant drobès tapytas paveikslas su paauksuotais spinduliais ir sidabriniu kryžiuku ${ }^{17}$. Naujasis altorius dekoruotas trimis tema ir chronologiškai tarpusavyje susijusiais siužetais. Pirmame tarpsnyje ikomponuotame paveiksle šventasis regi vizija, antrame miršta, trečiame kyla ị dangų. Pasirinktomis temomis Vilniaus altorius apibūdintinas kaip charakteringas amžiaus tendencijų atspindys, savitu meniniu sprendimu įamžinęs vèlyvojo baroko daileje populiariausias šv. Benedikto gyvenimo scenas ${ }^{18}$.

Titulinį altoriaus kūrinį nutapęs Simonas Čechavičius èmèsi tuomet populiariausio benediktinų dailès siužeto (3 il.), kuriame perteikiamas šv. Grigaliaus Didžiojo Dialoguose aprašytas epizodas, žymintis šv. Benedikto „mistinio gyvenimo viršūnę "19. Biografo pasakojama, kaip vieną naktį Benediktas meldèsi vienuolyno bokšte ir, stovėdamas prie lango, išvydo tamsoje iš viršaus sklindančią už dieną šviesesnę šviesą. Stulbiname regèjime prieš jo akis buvo sutelktas visas pasaulis, tarsi aprèptas vieno saulès spindulio. Netrukus žèrinčioje šviesoje jis išvydo ì dangų angelų nešamą ugnini kamuoli su Kapujos vyskupo Germano siela. Dialogas tęsiamas klausančiojo nuostaba ir jam pateiktu giliu pasaulio regèjimo paaiškinimu. Pasak Grigaliaus, „vidinio regèjimo šviesa praplečia sielos ribas, ir ši taip pasklinda Dieve, jog tampa aukštesnè už pasauli “20, todèl išplèsta Benedikto dvasia ir galëjo regèti visą pasaulį, kuris yra žemiau Dievo. Popiežiaus manymu, Benediktas nukeliamas

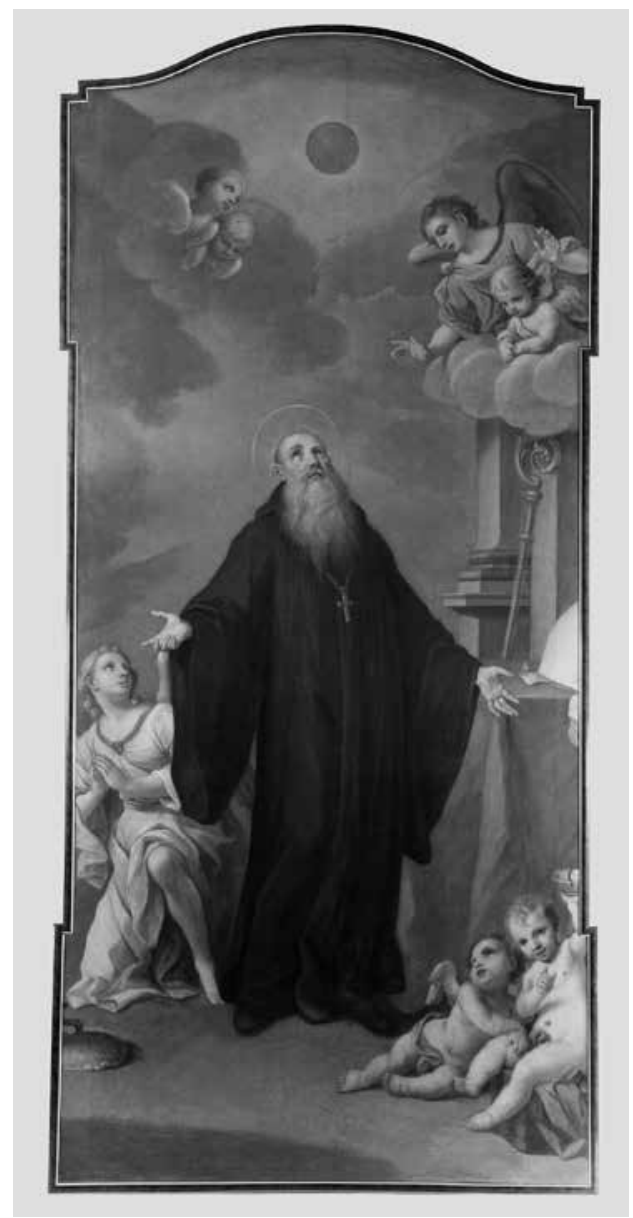

3 il. Simonas Čechavičius. $\breve{V}$. Benedikto vizija. 1756-1758. Drobè, aliejus. Lietuvos dailès muziejus

anapus pasaulio ir todèl galejjo ji matyti. Pasakojime pateikiamos kelios svarbios detalès, kurias vizualiai išreikšti meninèmis priemonėmis ilgą laiką dailininkams buvo itin sudètinga užduotis. Esminiai elementai perkelti $\mathfrak{i}$ atvaizdus: Benedikto nukèlimas $\mathfrak{i}$ anapusybę, pasaulis šviesos spindulyje, retais atvejais vyskupo Germano siela ugniniame rutulyje ir kartais virš pasaulio esantis Dievas (Švč. Trejybès pavidalu). Šios pasakojimo gairès padeda geriau suprasti ir Čechavičiaus ikonografinius sprendimus. 
Vilniaus kūrinyje pirmiausia matyti vykstantis perkèlimas $\mathfrak{i}$ anapusybę. Paveiksle dailininkas kuria sąlyginę, nekonkrečią vizijos momentu atsivèrusią erdvę. Iš vienos pusès - vienuolio užnugaryje raudonu audiniu uždengtas stalas, dar toliau už jo matyti standartinis, dažnai to meto kūriniuose pasitaikantis elementas - monumentalios kolonos dalis, kuri tradiciškai simbolizuoja ryši tarp žemės ir dangaus. Apatinė dalis su baze ir pjedestalu yra matoma, o viršutinè dalis su kapiteliu pranykusi dangaus debesų ir šviesos fone.

Neatsiejamas šv. Benedikto viziją perteikiančių kūrinių elementas - Žemès rutulio simbolis. Jis vienu svarbiausių šv. Benedikto ikonografijos elementu tapo tik XVIII a. Iki tol šios vizijos epizodas benediktinu daileje buvo sutinkamas itin retai, o pasisekimo vizija neturejo del komplikuoto turinio, kurị perteikti ryžtasi tik išskirtiniais atvejais ${ }^{21}$. Šio, anksčiau dažniausiai perteikiamo siužeto kontrastas buvo istorija apie Benedikto sesers mirti, kai brolis išvydo jos siela sklendžiančia balandžio pavidalu ${ }^{22}$.

Potridentiniu laikotarpiu, Katalikų bažnyčiai skatinant barokinę raišką ir prièmus nuostatas, kad menai turètų išreikšti religines temas itraukdami emocijas, paveikdami stebėtoją jutimiškai, pakito ir vizualinè kalba ${ }^{23}$. Metafizinius reiškinius menininkai dažnai èmėsi reikšti materialaus pasaulio pavidalais. Toks principas buvo pritaikytas ir šv. Benedikto vizijos siužetui. Jo vizualinei plètotei esminę ịtaką turëjo vokiečių dailininko Cosmo Damian Asamo darbai, kuriuose dvasiniam turiniui atskleisti jis pasitelkè moksliniais stebejimais paremtus, galbūt paties matytus saulès ir mènulio užte- mimo ịvaizdžius, taip pat perteikdavo audru, žaibo ir visokiu neiprastu meteorologiniu reiškiniu efektus ${ }^{24}$. Tai, kad nebuvo ryškios ankstesnes tradicijos, leido jam sukurti nauja ir savita vizijos vaizdavimo principa, $k u$ ri greitai peréme ir kiti XVIII a. dailininkai. Apskritai Benedikto vizija XVIII a. tapo pagrindiniu vienuolijos simboliu ${ }^{25}$.

Pirmasis Asamo bandymas perteikti pasauli iš Grigaliaus teksto matomas Šveicarijos Einsiedelno benediktinų bažnyčios 1724-1727 m. freskoje ${ }^{26}$, kurioje Žemès rutuli dailininkas nutapè susietą su šv. Benedikto apoteoze. Kitas mėginimas atsiskleidžia $1726 \mathrm{~m}$. nutapytame paveiksle ${ }^{27}$, skirtame Kladburio vienuolyno Čekijoje altoriui. Tiek pirmuoju, tiek antruoju atveju šv. Benediktas žvelgia i virš jo esantį šviesos spinduliuose skendinti melsvą pasaulio rutuli. Antrajame kūrinyje virš rutulio įkomponuoti dar ir Švč. Trejybės asmenys. Šie darbai įkūnija du pagrindinius XVIII a. plitusius šv. Benedikto vizijos perteikimo principus vienu atveju vizija integruota $i$ apoteozę danguje, kitu - vaizduojamas žemiškojo ir dangiškojo pasaulio susidūrimas.

Čechavičiaus kūrinio kompozicijos centre stovinčios monumentalios vienuolio figūros žvilgsnis nukreiptas ị debesu properšoje, gelsvos spalvos šviesoje išryškèjusi raudoną rutuli. Lyginant ši sprendimą su dauguma viziją perteikiančių XVIII a. kūrinių, matyti neiprasta ir daug klausimų kelianti rutulio spalvos traktuote. Matyt, Čechavičius užsimojo drobèje pavaizduoti ne prieš šventojo akis viename saulès spindulyje sutelktą visą pasauli, bet kiek vèliau pasakojime pasirodžiusi i dangų kylanti ugnini rutuli su vyskupo Germano siela. 
Žengiant toliau ir klausiant, kodèl pasirinkta antroji pasakojimo dalis, o ne jau tuomet nusistovejusi pasaulio rutulio traktuotè, būtina pažvelgti i j ji iš Šv. Kotrynos bažnyčios interjero perspektyvos. Šiuo atveju kūrinio pirminè aplinka bažnyčioje leidžia suprasti, kad jam pritaikytas išskirtinis sprendimas darytas sąmoningai $\mathfrak{i}$ interjerą žvelgiant kaip $\mathfrak{i}$ visumą. Apgalvotoje ikonografinejje programoje tarp titulinio šio altoriaus paveikslo ir Didžiojo altoriaus antrojo tarpsnio paveikslo atsiskleidžia esmiai ryšiai. Akivaizdu, kad šv. Benedikto vizijos siužetas iki galo ikonografiškai sukurtas Didžiajam altoriui nutapius Švč. Trejybės atvaizdą ${ }^{28}$ su didžiuliu mėlynu pasaulio rutuliu Sūnui ir Tèvui po kojomis. Tokiu itin kūrybišku būdu dailininkas perteikė abi šv. Grigaliaus Didžiojo pasakojimo dalis ir sukūrè autentišką, unikaliu sprendimu iš kitu šios temos kūrinių išsiskiriančią kompoziciją.

Kūrinio ikonografija išties turtinga panaudotu atributų. Šalia šv. Benedikto išdèstyta net keletas jų. Pirmiausia pažymètina, kad kompozicijoje stipriai išreikštas abato statusas, vaizduojamajam suteikiant tris priderančias insignijas. Juodą abitą vilkinčiam patriarchui ant kaklo kaba auksinis pektoralas, ant stalo pastatyta balta mitra, i sieną atremtas pastoralas. Kiti du atributai susiję su vienuolio gyvenimu. Vienas iš septynių kūrinyje pavaizduotų angelų laiko suskilusią taurę su iš jos kyšančia gyvate. Pastaroji simbolizuoja nuodus, o indo įskilimas primena stebuklingą sąmokslo atskleidimą.

Greta šventojo koju ikomponuotas duonos kepalas su gyvate. Tai trečias kūrinio elementas, susijęs su specifiniu šv.
Benedikto gyvenimo i̇vykiu, dar vienu bandymu ji nunuodyti, pasibaigusiu nedorų kẻslų išaiškinimu. Šv. Grigalius pasakoja, kaip vienas kunigas, vardu Florencijus, troško tokios garbès, kokią savo gyvensena tarp žmonių buvo igijęs Benediktas. Pavydo apakintas, jis siuntė užnuodytos duonos kepalèli tarsi dovaną. Benediktas ji prièmè, tačiau vẻliau, supratęs apie nuodus, paliepè pas ji kasdien atskrendančiam varnui nunešti duoną ten, kur jos nepasieks nė vienas žmogus, ir šis tai padare $\dot{e}^{29}$. Šis įvykis su užnuodyta duona apskritai šv. Benedikto atvaizduose prisimenamas kiek rečiau, nei bandymas nunuodyti vynu. Jam pavaizduoti tradicinèje ikonografijoje paprastai pasitelkiamas varnas su duonos kepalèliu, nešamu snape ar gulinčiu šalia. Čechavičiaus pasirinkimas nutapyti duonos kepalą su gyvate, kaip ir vaizduoti ugnini rutuli, yra nestandartinis, ikonografiniu požiūriu išskirtinis, parodantis dailininko kūrybini paslankumą. Tokią variacija, matyt, nulemė prasminès sąsajos su minètu taurès atributu.

Antrajam altoriaus tarpsniui buvo skirtas šv. Benedikto mirti vaizduojantis paveikslas ${ }^{30}$, kuriam Čechavičiaus mokiniai panaudojo Lazzaro Baldi $1685 \mathrm{~m}$.

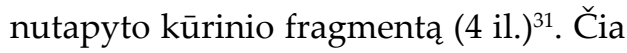
perteikta akimirka, kai šv. Benediktas, prilaikomas triju baltomis kamžomis vilkinčių mokinių, palieka ši pasaulị. Jo rankos išskleistos i i šonus, galva pakelta, žvilgsnis nukreiptas į atsiveriantị dangu, išbalęs veidas byloja apie išsekintą kūną ir gęstančią gyvybę. Pirmavaizdyje pagrindinius veikejjus supa būrys angelų, aukščiau danguje broli pasitinka prieš kelias dienas mirusi sesuo Skolastika. 


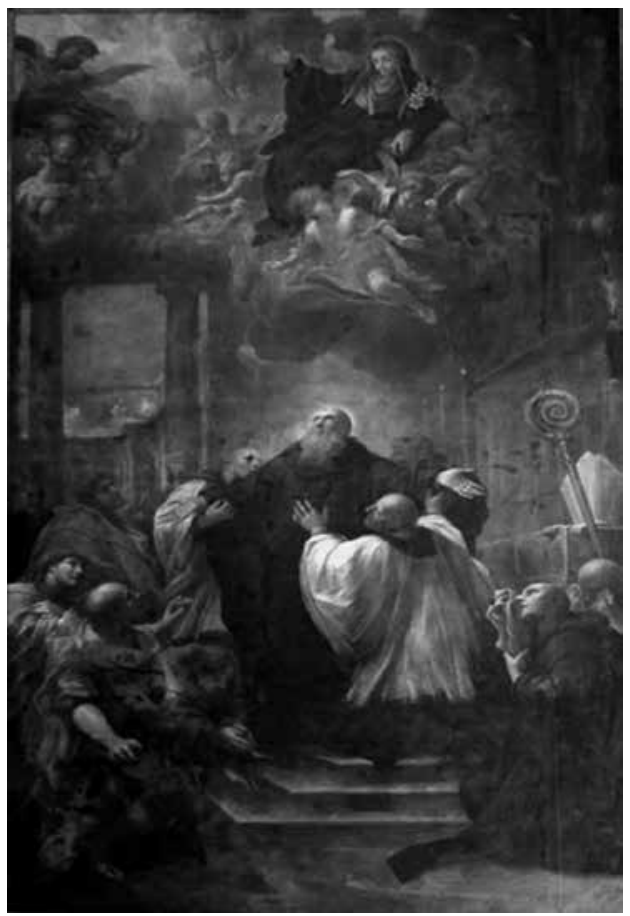

4 il. Lazzaro Baldi. ̌̌v. Benedikto mirtis. 1685. Drobè, aliejus. S. Maria in Campo Marzio bažnyčia. Italija

Tokia pirmavaizdžio ikonografija Vilniaus šv. Benedikto altoriui nebuvo tinkama dèl visuminio interjero ikonografinès programos sprendimo. Šiam kūriniui, kaip ir prieš tai aptartajam, reikia ¡kontekstinimo. Kaip ir pirmojo, šio siužetas, rodos, taip pat veržiasi už drobès ribų. Ši kartą prasminès sąsajos ji jungia su altoriu vainikuojančia skulptūrine dalimi, kuri kitoje medijoje pratęsia irvisai užbaigia siužeto kompoziciją. Tai sprendimas, taip pat rodantis itin kruopštu ikonografinès programos apmąstyma, tapytojo ir skulptoriaus bendradarbiavima, barokišką menų sintezę.

Remiantis šv. Grigaliaus Didžiojo pasakojimu, paskutines akimirkas abatas praleido bažnyčioje su ji ten nunešusiais mokiniais, čia paskutini kartą prièmè Viešpaties kūną ir kraują kulminaciniu momentu prilaikomas mokinių atsistojo, iškèle rankas i dangu ir, tardamas maldos žodžius, paliko ši pasauli ${ }^{32}$. Kalbant apie altoriaus ikonografini sprendimą, svarbi ir antroji 38-ojo Dialogų skyriaus dalis, kurioje biografas aprašo mokiniams duotą ženklą ir savotišką irodymą, kad ju mokytojo dvasia tuojau pat buvo paimta į dangu. Du mokiniai, tądien buvę toliau už vienuolyno, išvydo tą pati ženkla, nuo vienuolyno i̇ dangų nusitęsusi kelią, užklotą prabangiais kilimais ir nušviestą tūkstančiu šviesulių. Tuomet jiems pasirodè didingos išvaizdos vyras ir pasakè, kad tai kelias, kuriuo palaimintasis Benediktas pakilo i̇ dangu $u^{33}$.

Šv. Benedikto mirties siužeto XVIII a. pavyzdžiuose šiauriniame Alpių regione susiformavo tendencija viename kūrinyje ar irenginyje sujungti dvi pasakojimo dalis. Šio pobūdžio pavyzdžiuose apatinejje kūrinio erdveje sutelktos šv. Benedikto ir mokinių figūros, kur atskleidžiamas paskutinès Komunijos ar mirties momentas, o viršutinejje kompozicijos dalyje ar atskirame altoriaus kūrinyje matyti i dangų nusidriekęs žibintų apšviestas kelias ir juo kylanti šventojo siela apnuogintos figūros pavidalu. Šios ikonografinès sandaros savitai interpretuotų detalių esama ir Vilniaus šv. Benedikto altoriuje.

İrengini vainikuojančiame horeljefe Johnas Hedelis perteikè dangaus debesu apsuptą vienuoli, angelų keliamą aukštyn i plačiai atvertą Dievo Tẻvo glèbi (5 il.). Iš pirmo žvilgsnio kompozicija primena gana iprastą apoteozès scena, tačiau kūrinio detalès sugestijuoja moki- 
nių paliudytą kilimo i̇ dangų momentą. Judejimą čia aiškiai išreiškia šv. Benediktą apglèbę angelai. Laukimo veiksmą taip pat rodo apkabinimui išskleistos Dievo Tèvo rankos. Tiesioginius ryšius su kilimo i̇ dangu pasakojimu ir tokio pobūdžio kūriniais išreiškia debesyse ikomponuoti žibintai, sukonkretinantys erdvę ir leidžiantys suprasti, kad skulptorius originaliai perteikia žibintu kelio pabaigą danguje.

Vilniaus kūriniui artimos ikonografijos skulptūrinę kompoziciją $1741 \mathrm{~m}$. Ochsenhauseno vienuolyno sakyklai sukūrè Egidas Verhelstas (6 il.), kurioje benediktinų tévas kyla žibintais apšviestu debesų taku i dangų. Ji lydi angelai, o viršutinèje reginio dalyje spinduliuoja Švč. Trejybę simbolizuojantis trikampis.

Apibendrinant Vilniaus šv. Kotrynos bažnyčios šv. Benedikto altorių, galima sakyti, kad tai ypatingai apgalvotos, gilios ir savitai išreikštos ikonografijos pavyzdys, pranokstantis vieno kūrinio ribas, glaudžiai susietas su bažnyčios interjero kontekstu, praplečiančiu įrenginio elementu ikonografiją, ją praturtina, leidžia patikslinti turini ir suteikia pagrindo naujoms ižvalgoms. Simono Čechavičiaus darbe perteiktas šv. Benedikto vizijos siužetas pasižymi išskirtiniais, savitai ir kūrybiškai interpretuotais ikonografiniais sprendimais. Atskleistos prasminès sąsajos su Didžiojo altoriaus Švč. Trejybès paveikslu, kuriam pasirinktas ikonografinis tipas su pasaulio rutuliu po Dievo kojomis parodè, kad neiprastai vizijos siužetą

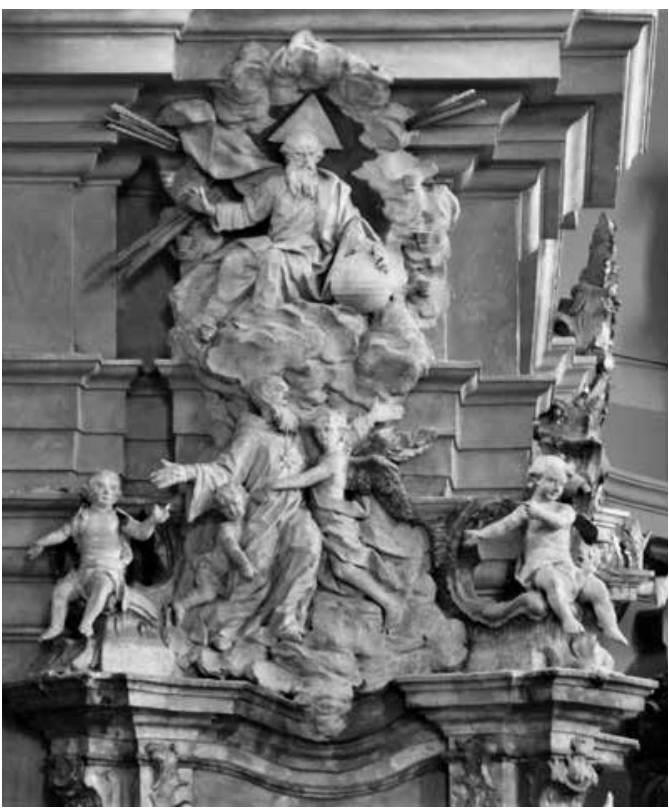

5 il. Jonas Hedelis. Šv. Benedikto kilimas i dangų. 17591760. Stiukas. Vilniaus šv. Kotrynos bažnyčia

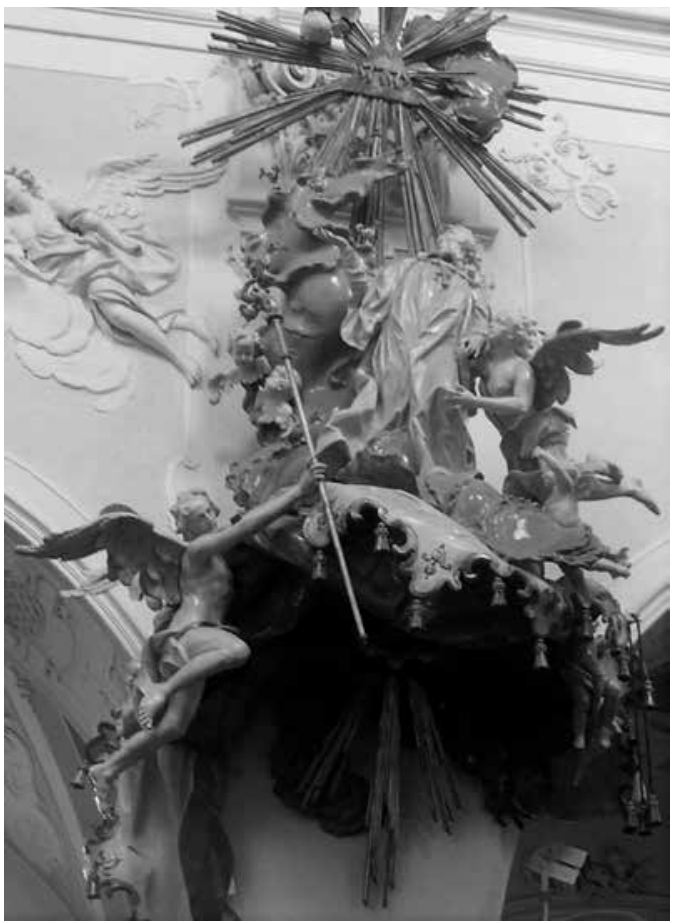

6 il. Egid Verhelst. $\breve{S}$ v. Benedikto mirtis. 1741. Marmuras. Ochsenhausen vienuolynas. Vokietija 


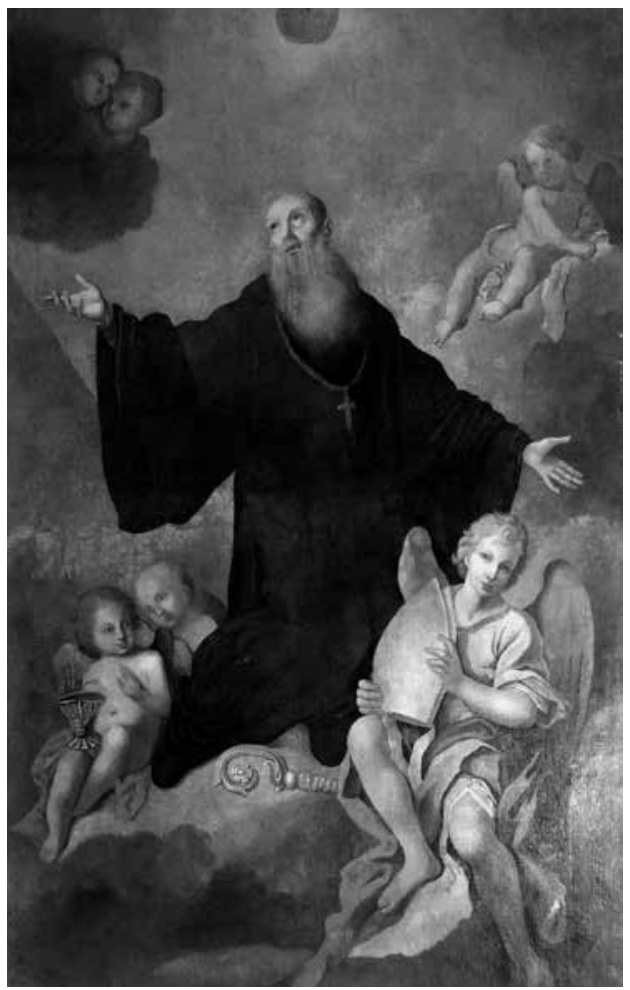

7 il. Simonas Čechavičius. Šv. Benediktas. 17561758. Drobè, aliejus. Raudondvario šv. Kūdikèlio Jėzaus Teresės bažnyčia

vaizduojantiems analogams Europoje, Čechavičiaus drobejje šv. Benediktas regi ne visą pasauli, bet $i \mathfrak{d}$ dangu ugniniame rutulyje kylančią vyskupo Germano sielą. Tęstinès, dviejose medijose įamžintos ikonografijos sprendimas sukurtas antrojo tarpsnio šv. Benedikto mirties paveikslui ir altorių vainikuojančiai skulptūrinei kompozicijai. Nors pastaroji iš pirmo žvilgsnio primena šventojo apoteozę, vis dèlto ji traktuotina kaip šv. Benedikto kilimo ị dangų siužetas. Tai rodo XVIII a. šiauriniame Alpių regione plitę, ikonografija ị Vilniaus atveji panašūs kūriniai, kuriuose integraliai naudoti du šv. Grigaliaus Didžiojo užrašyti pasakojimai apie šventojo mirti ir kilimą i dangų.
Reikšmingą šv. Benedikto atvaizdų dali sudaro trys altoriniai vienuolio apoteozę perteikiantys paveikslai, šiandien išlikę Senuju Trakų ${ }^{34}$ Viešpaties Apreiškimo Švč. M. Marijai ir šv. Benedikto, Kauno $^{35}$ šv. Mikalojaus ir Raudondvario šv. Kūdikèlio Jèzaus Teresès (7 il.) bažnyčiose. Dokumentai, tiesiogiai fiksuojantys dailininko darba, nè vienu atveju neišliko, tačiau kūriniai įvairiu metu imti sieti su žymiuoju Čechavičiumi dèl jo kūrybai artimos atlikimo manieros ir jam būdingų vizualinių sprendimų. Datuojami XVIII a. II puse ir, konkrečiau, siejami su metais, kai dailininkas vykdè pagrindinį užsakymą Vilniaus šv. Kotrynos bažnyčioje. Kūriniai akivaizdžiai susiję dèl juose panaudotos identiškos kompozicijos, besiskiriančios vos keliomis detalemis.

Apie Senujuc Trakų bažnyčioje buvusius šv. Benedikto atvaizdus šiandien seniausius duomenis pateikia $1799 \mathrm{~m}$. inventorius. Dokumente kalbama apie tuomet bažnyčioje buvusius keturis šv. Benedikto paveikslus. Minimas altoriaus paveikslas paprastame rème (porinis šv. Skolastikos altoriaus paveikslui), presbiterijoje ant sienos drožejuc darbo auksuotame rème, taip pat porinis auksuotame drožèjų darbo rẻme zakristijoje virš durų ir ketvirtas - nešiojamame altorèlyje $\mathrm{e}^{36}$. $1820 \mathrm{~m}$. altoriaus paveikslas ivvardijamas kaip didelis ir turintis staliaus darbo rèmus. Presbiterijoje kabejjo šv. Benedikto ir šv. Skolastikos maži paveikslai drožèjų darbo auksuotuose rèmuose ${ }^{37}$. Panašu, kad naujoje vietoje minimi anksčiau zakristijoje kabejję kūriniai. 1830 m. inventoriuje kūriniai vietas išlaikè, ir i̇domu, kad prie jau ankstesnių žinių vizitatorius pridejjo tapybos profesionalumo ivverti- 
nimus. Jo nuomone, altorinis šv. Benedikto paveikslas ir kabejjęs presbiterijoje nutapyti "gana gerai“, o šv. Skolastikos paveikslų tapyba apibūdinama kaip "gera“ ir netgi „labai gera“"38.

Pirmame po vienuolyno uždarymo dokumente, surašytame $1850 \mathrm{~m}$., pateikti altoriniu paveikslų matmenys. Vizitatoriaus teigimu, ju ilgis buvo penkios uolektys, plotis - dvi $(\sim 300 \times 120)$. Panašaus dydžio paveikslai minimi ir vèliau iki naujos bažnyčios pastatymo. Pokyčiu būta ir perkabinant paveikslus. Tuomet užfiksuotas nedidelis, greičiausiai tas pats šv. Benedikto paveikslas, kabëjęs presbiterijoje, tačiau senasis šv. Skolastikos atvaizdas buvo pakeistas ị drobę, vaizdavusią šv. Joną Krikštytoją.

Pastatytoje naujoje bažnyčioje $1901 \mathrm{~m}$. apsilankęs vizitatorius pažymëjo, kad šventoveje tuomet būta Čechavičiaus tapytu šv. Benedikto ir Skolastikos altoriniu paveikslų, kurių autorystė pagrindžia perkèlimą iš senosios bažnyčios. Šiame ir vèlesniuose vizitacijų aprašuose paveikslų išmatavimai nebeminimi. Iš 1919 m. dokumento sužinome, kad altorinès drobès nukentëjo per kara, tačiau šv. Benedikto atvaizdas vis dar randamas savo vietoje ${ }^{39}$. Ji per $1921 \mathrm{~m}$. vykdytą interjero rekonstrukciją atnaujino dailininkas Kazimieras Kviatkovskis ${ }^{40}$. Greičiausiai šio atnaujinimo metu buvo pakeistos kelios kūrinio ikonografijos detalès. Kauno ir Raudondvario kūrinyje matyti Vilniaus šv. Kotrynos bažnyčios šv. Benedikto altoriaus tituliniam paveikslui artimi sprendimai. Drobėse panaudotas raudonas vizijos rutulys ir balta abato mitra, o Senuju Trakų kūrinyje rutulys mèlynas, o mitra su aukso spalvos pakraščiais ir kryžiumi plokštumos vidu-

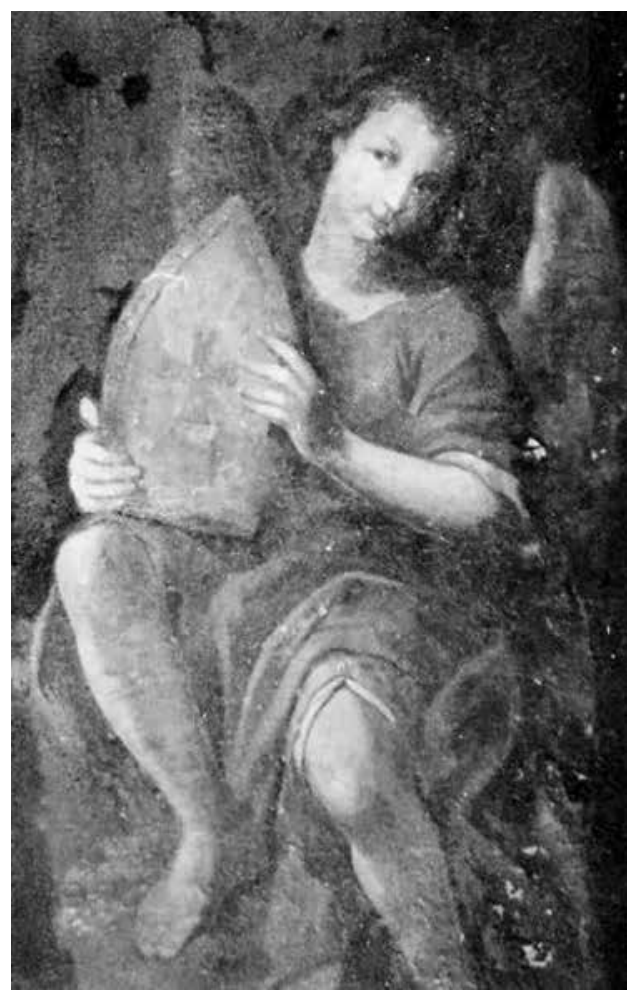

8 II. Senųjų Trakų paveikslo „ک̌̌v. Benediktas“ detalè prieš restauravimą $1995 \mathrm{~m}$. Manto Matuizos asm. archyvas

ryje. 1995-1996 m. kūrinio restauravimo metu buvo pašalinta apie 80 procentu vẻlesnių užtapymų ${ }^{41}$. Tai leidžia manyti, kad dabar besiskiriantys elementai yra palikti vèlesni užtapymai. Tikètina, kad atnaujinant sugadintą paveikslą $1921 \mathrm{~m}$., Kviatkovskis rèmėsi Vilčinskio albume buvusia pagal Raudondvario paveikslą sukurta litografija, kurios vaizdas kur kas artimesnis Senųjų Trakų, o ne Raudondvario kūriniui. Pavyzdžiui, prieš restauravimą darytoje nuotraukoje abato mitra neturèjo kaspinu (8 il.), o tai atitinka vaizdą litografijoje, tačiau restauravimo metu jie buvo atidengti. Šios sąsajos paaiškina, kodèl kūrinys minètais sprendimais skiriasi nuo kitų dviejų 
Grupès kompozicijose gelsvos šviesos persmelktų debesų fone vaizduojama pusiau klūpanti šv. Benedikto figūra. Vienuolio rankos plačiai išskleistos, žvilgsnis nukreiptas į melsvą viršuje švytinti pasaulio rutuli. Dailininkas šventajam perteikti pasirenka tuomet jau iprastą tonzūruoto ilgabarzdžio patriarcho tipažą. Prie šventojo kojų paguldytas pastoralas, kitus atributus - mitrą ir suskilusią taurę su gyvate - laiko šventajam asistuojantys angelai. Kompozicijos skiriasi keliomis detalèmis. Be skirtingai traktuoto Senujų Trakų paveikslo vizijos rutulio ir puošnesnès mitros, Kauno atvaizde, ji pritaikant altoriaus nišai, atsisakyta viršutinès dalies angelų.

Kūrinius siejant su Čechavičiaus kūryba, galima pabrèžti faktą, kad dailininkas nevenge kartoti kompozicijų ir veikejjų tipažų. Tai liudija vienas kitam artimi Vilniaus benediktinių ir Tykocino bažnyčios Švč. Trejybės paveikslai. Lvovo meno galerijos „Šv. Pranciškaus, gaunančio indulgenciją" paveikslo angelo tipažo pakartojimas trijuose šv. Benedikto paveiksluose.

Turbūt įdomiausias Čechavičiaus šv. Benedikto atvaizdo atsiradimo Raudondvaryje klausimas. Pagrindiniai šito liudininkai - keliautojai Feliksas Nowakowskis ir Teodoras Tripplinas, kurie 1858 m. išleistuose kelionių po Lietuvą aprašymuose pažymëjo, kad Tiškevičių koplyčioje kabantys šv. Benedikto ir Skolastikos paveikslai buvo nutapyti Čechavičiaus ir įsigyti Trakuose ${ }^{42}$. Vis dèlto remiantis šiu dienų tyrimais, šio įsigijimo aplinkybės ir vieta tebèra iki galo neišaiškinta ${ }^{43}$. Žvelgiant $i \mathfrak{i}$ archyvinius dokumentus, reikia išskirti kelias reikšmingas detales.
Naujai pastatytos Raudondvario bažnyčios koplyčioje šv. Benedikto ir Skolastikos paveikslai, nutapyti Čechavičiaus, minimi nuo $1852 \mathrm{~m} .{ }^{44}$ Senujų Trakų vienuolynas panaikintas 1845 m., o 1849 m. bažnyčia paversta parapine ir tuomet atlikti jos tvarkymo darbai. $1850 \mathrm{~m}$. altoriuje tebebuvo didelių matmenų kūrinys. Vèlesniuose dokumentuose iki naujos bažnyčios pastatymo minimas panašus dydis. Svarstant apie kitas paveikslo izsigijimo galimybes, atkrenta ir Seniesiems Trakams priklausančios Pivašiūnų prepozitūros paveikslo perdavimo variantas, nes po vienuolyno panaikinimo iki 1853 $\mathrm{m}$. benediktinų vienuolis buvo likęs eiti klebono pareigas, o bažnyčia nenustojo veikti ${ }^{45}$. Išlikusiuose dokumentuose taip pat niekur nebuvo minima jokio šv. Skolastikos paveikslo. Kitokia situacija susiklostė Pašaltuonyje. Bažnyčia ir vienuolynas buvo uždaryta dar $1831 \mathrm{~m}$. ir išliko nenaudojama iki 1858 m., kada buvo pritaikyta parapinei veiklai. $1831 \mathrm{~m}$. bažnyčios antrame altoriuje paminèti šv. Benedikto ir šv. Skolastikos paveikslai ${ }^{46}$, o $1862 \mathrm{~m}$. inventorius užfiksavo altoriuje buvus tik seną šv. Skolastikos paveikslą antrame tarpsnyje ${ }^{47}$. Turint mintyje tai, kad Pašaltuonio vienuolynas funduotas 1756 m., ir tai, kad nauji altoriniai šv. Benedikto ir Skolastikos paveikslai galejo būti sukurti Senujuc Trakų vienuolynui prieš pat $1757 \mathrm{~m}$. gaisrą ${ }^{48}$, tampa labai realu, kad Vilniuje tuomet dirbusiam Čechavičiui buvo duotas dvigubas užsakymas. Šioje benediktinų bažnyčių atnaujinimo bangoje būta ir Kauno benediktinių, užsakiusių tokios pat kompozicijos šv. Benedikto paveikslą savo šventovei. Greičiausiai netrukus bažnyčioje buvo įrengtas ir šv. Skolastikos altorius, kurio pa- 
veikslas tebėra išlikęs iki šiandienos. Jis nutapytas remiantis šv. Benedikto paveikslu vieno iš Čechavičiaus mokyklos atstovu ${ }^{49}$, galbūt dirbtuvių mokinio ${ }^{50}$.

Po Pašaltuonio prepozitūros panaikinimo drobè su šv. Benediktu galejjo toliau būti bažnyčioje arba persivežta i̇ Senuosius Trakus ir bet kuriuo atveju nupirkta grafo. Tačiau pirkimo versiją komplikuoja Pašaltuonio altoriaus antrajame tarpsnyje buvusio šv. Skolastikos paveikslo užfiksavimas dokumentuose tiek 1831 m., tiek 1862 m. Jei Čechavičius galejo nutapyti abu Pašaltuonio altorinius kūrinius, abejotina, kad buvo nupirktas tik vienas jų. Žvelgiant i Senuju Trakų bažnyčios inventoriaus kaitą 1830$1850 \mathrm{~m}$. laikotarpiu, šv. Benedikto paveikslų šventovëje taip pat nepadaugëjo, kita vertus, $1850 \mathrm{~m}$. bažnyčioje nebebuvo šv. Skolastikos mažojo atvaizdo iš presbiterijos, jo vietoje tuomet kabëjo drobė su šv. Jonu Krikštytoju. Mažai tikètina, kad galèjo būti nupirktas šv. Benedikto iš Pašaltuonio ir šv. Skolastikos iš Senujų Traku paveikslų derinys, juolab kad abu atvaizdai Raudondvaryje $1852 \mathrm{~m}$. priskiriami Čechavičiui. Todèl tenka konstatuoti, kad kūriniu patekimo ị Raudondvari klausimas tebėra neatsakytas.

Kalbant plačiau apie kūrinių ikonografiją ir galimas i̇takas, žvilgsni prasminga nukreipti $\mathfrak{i}$ europini kontekstą: XVII a. po truputi gausejjo kompoziciju Šv. Benedikto išaukštinimo danguje tema. Vieną iš tokių molbertinès tapybos kūrinių, dabar esantị Vokietijos Weingarteno bazilikoje, XVII a. viduryje nutapè Johannas Christophas Storeris (9 il.). Šio dailininko ir Čechavičiaus drobès artimos komponavimo principu, monumentalios figūros vaizdavimu, barokiškai raiškia

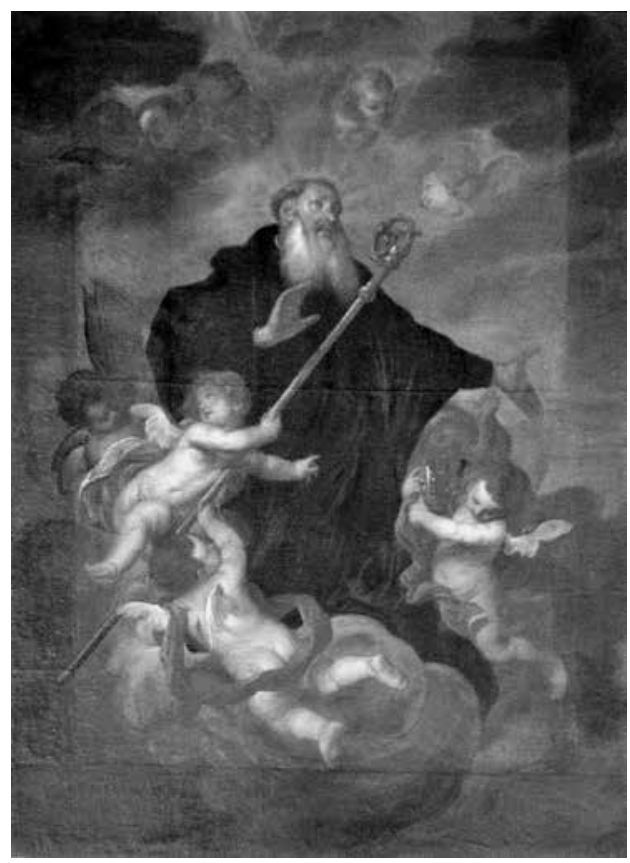

9 il. Johann Christoph Storer. $\check{S}_{v}$. Benediktas. XVII a. vid. Drobė, aliejus. Weingarten HI. Martin bazilika. Vokietija

gestikuliacija, dangaus fono traktuote, būdingu pastoralo, mitros ir taurès atributų naudojimu. Esminis skirtumas tarp šimtmečiu vienas nuo kito nutolusių kūriniu - lietuviškajai kompozicijai XVIII a. būdinga jungtis su šventojo regèta vizija. Taip pat galima prisiminti minètą Asamo drobę, kurioje perteiktas vizijos ir apoteozès junginys.

Vis dèlto Lietuvos apoteoziniams šv. Benedikto paveikslams tiesioginę itaką darę kūriniai randami benediktinų naudotuose mišioluose, kur būta grafiniu šventojo atvaizdų ${ }^{51}$. Tai atskleidžia ryškios Čechavičiaus kūrinių sąsajos su Jacopo Leonardi sukurta kompozicija ${ }^{52}$, esančia $1768 \mathrm{~m}$. leidinyje, kuri pirmiesiems artima figūros komponavimo pobūdžiu, tipažu, regimos vizijos ir dalies atributų integracija. 
Kauno ir Raudondvario drobėse regimas įdomus Čechavičiaus kūrybinis niuansas - raudono rutulio vaizdavimas, kuris nepaklūsta įsivyravusioms laikotarpio tendencijoms. Panašu, kad sprendimas galejjo būti nulemtas Vilniaus bažnyčiai sukurtos kompozicijos sprendimo.

Pastebima Čechavičiaus îtvirtintos kompozicijos sklaida ir vèlesniu laiku kurtuose šv. Benedikto atvaizduose. Senujuc Trakų bažnyčios didžiajame altoriuje šiandien išlikusi XVIII a. II puse datuojama skulptūra, kuri pakartoja paveikslo figūros pozą. Šios kompozicijos ikonografiškai redukuoti XIX ir XX a. tapybiniai sekiniai išlikę Šiluvos ir Vidsodžio bažnyčiose.

Apibendrinant XVIII a. šv. Benedikto atvaizdų visuma, matyti keturioms Lietuvos benediktinų bažnyčioms šv. Benedikto altorinius atvaizdus maždaug 1756-1758 m. sukūrusio Čechavičiaus didžiulè įtaka. Gilinantis i paveikslo atsiradimo Raudondvaryje klausimą ir ieš- kant tvirtesnio pagrindo prieaiai, kad kūrinys nupirktas iš Senujuc Trakų vienuolyno ar Pašaltuonio prepozitūros, ivertinus turimus duomenis tenka konstatuoti, kad klausimas vis dar yra atviras.

Iš triju vienodos kompozicijos Čechavičiaus kūrinių išsiskiria Senųju Trakų drobė. Joje prieš restauravimą XX a. pabaigoje ir dabar izžvelgiamos sąsajos su XIX a. viduryje pagal Raudondvario paveikslą sukurta litografija. Tai suteikia pagrindo manyti, kad dabartinis vaizdas nėra visiškai autentiškas Čechavičiaus sprendimas, o Pirmojo pasaulinio karo metais sugadintos drobès atnaujinimo rezultatas. Čechavičiaus kompozicija seka XVIII a. pradžioje suformuotu šv. Benedikto apoteozès ir pasaulio vizijos junginio ikonografiniu principu, tačiau specifiškumo jai suteikia dailininko dèl patirtos Vilniaus paveikslo įtakos pakartotas nuo tradicinio vaizdavimo nutolęs raudono rutulio motyvas. Kompozicijai naudojamos tradicinès abato insignijos ir îskilusios taurès su gyvate atributas.

\section{KINTANTI XIX A. IKONOGRAFIJOS KALBA}

XIX a., carinès priespaudos metais, vienuolynų uždarymo akivaizdoje nauju šv. Benedikto altorinių atvaizdu benediktinams sukurta nebuvo. Tačiau pažymètina tai, kad pamaldumo tradicijos dažniausiai buvo tęstos vienuolyno bažnyčias pavertus parapinėmis. Paprastai tokiais atvejais ir toliau naudoti senieji atvaizdai, tačiau šiuo požiūriu išsiskiria Pivašiūnų bažnyčia. 1883-1894 m. jos interjerą papildant naujais kūriniais, buvo nutapyta nauja drobė su šv. Benedik$\mathrm{tu}^{53}$. Kūrinyje naudojama novatoriška realizmo srovès stilistika, praktikuojama tuo metu bažnytinę dailę atnaujinti siekiančių menininkų $\mathrm{c}^{54}$. Be savito ir autentiško realistinio vaizdavimo būdo, paveiksle taip pat ryški neoromantizmo ittaka, jam būdingas simboliškumas ir tam tikras dramatizmas. Tad šių dvieju stilių derinys turi išties įdomią išraišką. Drobė turtinga ikonografine kalba, tad, siekiant atskleisti kūrinio turini, verta i ją isigilinti.

Šv. Benediktas vaizduojamas suklupęs ir karštai maldai sukabinęs rankas, kurios, rodos, suspaustos taip stipriai, kad net vietomis pamèlynavusios. Šiuo 
gestu autorius tarsi bando ittikinti drobèje vaizduojamo asmens nuoširdumu ir uolumu, primindamas Reguloje minimą atsidejjimą tyrai maldai „su ašaromis ir dèmesinga širdimi“ ${ }^{\star 55}$. Taip realistiškai perteikiant šventajij, kitaip nei iki tol, sureikšminamas jo materialumas ir apčiuopiamumas, asmuo priartinamas prie žemiškos pasaulio kasdienybės, patiria kovą ir vidini dramatizmą. Gilios šventojo akys kilstelètos kiek aukštyn, žvelgia $i$ tolius, atsiveriančius už priešais ant uolos pastatyto krucifikso ir atverstos knygos su vaikeli Jèzų laikančios Dievo Motinos atvaizdu. Benediktui parinktas tradicinis pražilusio senolio, benediktinu patriarcho tipažas. Veidas traktuotas realistiškai su rūsčiais, fiziškai išsekusio žmogaus bruožais. Ji tradiciškai dengia vešli barzda, galva pliktelëjusi. Vienuolis vilki iprastu abitu, šalia jo ant žemès pastatyta mitra ir paguldytas pastoralas. Be iprastų statuso atributu, taip pat pasirinkti du, primenantys šventojo gyvenimo istorijas. Už vienuolio nugaros, urvo gilumoje ikomponuotas suskilęs vyno indas ar ąsotis - savita istorijos apie bandymą nunuodyti ikonografinè variacija. Drobès viršuje įkomponuotas kitas ypač populiarus atributas, nurodantis dar vieną bandymą nunuodyti - sklendžiantis varnas su snape nešamu duonos kepalèliu. Šis pasirinkimas, kitaip nei anksčiau aptartame Čechavičiaus darbe, turi tradicinę išraišką. Kūrinys ypač i̇domus dèl jame naudojamo natūralaus kalnuoto peizažo fono, kuris byloja apie neoromantizmo itaką ir drobei suteikia ne tik savitą nuotaika, tačiau turi ir aiškią simbolinę reikšmę. Horizonto tolumoje ikomponuota bažnyčia su bokštu, už kalnų auštantis rytas ženklina Vakarų vienuolystès aušrą ir šv. Benedikto indèli i j jos atsiradimą.

Panašu, kad XIX-XX a. paveikslus tapant jau ne vienuoliams, imtasi aktualizuoti benediktinų ikūrèjo vaidmenį. Tam pasitelktas iprastas bažnyčios ar vienuolyno pastatu iterpimas it kompozicijos foną. Sprendimas pritaikytas šv. Benedikto atvaizduose, šiandien randamuose ne tik Pivašiūnuose, bet ir Kauno Švč. M. Marijos Ėmimo i dangų bažnyčioje ir Ugioniuose.

Paskutineje straipsnio dalyje aptartas vienintelis XIX a. šv. Benedikto altorinis atvaizdas, sukurtas Pivašiūnų bažnyčiai jau ten nebesant benediktinams. Altoriaus paveikslas nuo ankstesnių šv. Benedikto kūrinių skiriasi jam taikoma tuo metu novatoriška realistinès tapybos maniera, pakitusia nuotaika, racionaliu požiūriu i vaizduojamų objektų išraišką. Kompozicijoje atsisakyta vizijinès ar dangiškos erdvès kūrimo, asmeni įkomponuojant natūraliame peizaže ir traktuojant kaip žemiška, apčiuopiamą šio pasaulio žmogu, išsekusi, tačiau aistringai atsidavusi Dievui. Dailininkas peizaže su tolumoje ryškejjančia bažnyčia savitai užkodavo gilią simbolinę reikšmę, pabrèžiančią benediktinų ikūrèjo statusą. Kompozicijoje panaudotas Vakaruose itin dažnas tradicinis varno, snape nešančio duonos kepaliuka, atributas, kuris Lietuvoje tèra matomas tik šiame darbe. Taip pat drobejje ikomponuotas suskilusio indo atributas, tačiau jis čia jau ne simbolinė taurè su gyvate, bet nuo tradicinès ikonografijos nutolusio, archeologini pagrindą turinčio, paprasto isskilusio vyno ąsočio pavidalo. 


\section{APIBENDRINIMAS}

İsigilinus i XVII-XIX a. sukurtus šv. Benedikto altorinius atvaizdus, juose atsiskleidžia aiški trijų amžių skirtis. Dviejuose nagrinètuose XVII a. vidurio barokiniuose kūriniuose jaučiama dar viduramžiais susiklosčiusios ikonografijos raiška. XVIII a. II pusès kūriniuose kartojamos šio amžiaus Europoje populiariausios barokinès mirties, vizijos ir apoteozès scenos. XIX a. pabaigos kūrinys, nutapytas derinant realizmo ir neoromantizmo stilius, atskleidžia pakitusi požiūrị i tradicinę ikonografiją šventojo ir jo aplinkos, atributu vaizdinès išraiškos racionalizavimą.

Apibendrinant šv. Benedikto vaizdavima, galima konstatuoti, kad nuo XVII a. Lietuvoje issitvirtino benediktinu patriarcho, vaizduojančio pražilusị ilgabarzdị senoli, tipažas. Nagrinètoje grupejje bebarzdžio vyro tipažu išsiskiria tik Kauno benediktinių šventoveje buvusi skulptūra.

Šv. Benedikto atributus galima suskirstyti į dvi grupes. Pirmoji akcentuoja šventojo priklausomybę benediktinams, einamas abato pareigas, Regulos autoriaus ir vienuolijos įkūrëjo statusą. Šventasis visada vilki juodą abitą. XVIII a. kūriniuose jam ant kaklo visuomet kaba pektoralas. Tapytuose atvaizduose šalia ant stalelio ar tiesiog ant žemés padèta arba angelo laikoma mitra ir taip pat ant žemės ar debesies paguldytas, ar šalia pastatytas pastoralas primena abato pareigu atsisakymą. Rankoje pastoralą laiko tik XVII a. skulptūra. Išskirtiniu atributu abato pareigos pabrèžtos Kražiu paveiksle - šventasis apsiaustas puošnia kapa. Vienuolinès regulos autorystė XVII a. atvaizduose išryškinama laikant knygą. XIX a. jau ne benediktinams kurtame Pivašiūnu paveiksle apie vienuolijos įkūrimą byloja brèkštančios aušros peizaže ikkomponuota bažnyčia. XVIII a. atvaizdu ikonografija dvieju pastarųju aspektų neakcentuoja. Čia svarbūs stebukliniai, mistiniai vienuolio patyrimai.

Kita atributu grupè primena šv. Benedikto gyvenimo įvykius. Analogiškai Vakaru dailei, Lietuvoje populiariausias iskilusios taurès su joje esančia gyvate atributas, primenantis stebuklingą išsiaiškinimą apie užnuodytą vyną. Jis panaudotas visuose tyrime nagrinètuose kūriniuose, išskyrus esanti Kražiuose. Vilniuje bei Pivašiūnuose panaudotas dar ir užnuodytos duonos atributas, kuris pirmuoju atveju savitai perteiktas duonos ir gyvatès simboliu, o Pivašiūnuose sekama tradiciniu vaizdavimu varnas duonos kepalèlį neša snape.

Išskirtinę vietą Lietuvos šv. Benedikto ikonografijoje užima S. Čechavičiaus 1756-1758 m. sukurti darbai. Juose perteiktos aktualiausios, bendrąsias to laikmečio tendencijas atspindinčios scenos. Ikonografiniu požiūriu kompozicijos traktuotos autentiškai ir išskirtinai. Kitaip nei tuomet buvo būdinga šio siužeto kūriniams Europoje, kompozicijose perteiktas šv. Benediktas regintis ugnini raudonos spalvos rutuli, o ne mélyną pasaulio rutulį. Sprendimą paaiškina ypač gerai apgalvota Vilniaus benediktinių bažnyčios interjero ikonografinè programa. Ikontekstinus šv. Benedikto, reginčio vizija, paveikslą, atsiskleidè jo 
prasminis susietumas su didžiajame altoriuje ittaisytu Švč. Trejybės paveikslu, kuriame pavaizduotas Dievui po kojomis esantis pasaulio rutulys. Tokiu būdu dailininkas viename kūrinyje šv. Grigaliaus Didžiojo Dialoguose užrašytą vizijos pasakojimą pradeda, o kitame ji užbaigia. Artimas principas pritaikytas antrojo tarpsnio šv. Benedikto mirties paveiksle ir altorių vainikuojančioje bei pradètą pasakojimą užbaigiančioje vienuolio dvasios kilimo i̇ dangų skulptūrinëje kompozicijoje. Netradicinį ugninio rutulio ikonografini sprendimą Čechavičius perkèlè ir pakartojo drobėse, skirtose Senujų Trakų, Pašaltuonio ir Kauno šventovėms, kuriose XVIII a. dailei bū- dingu būdu sujungè šventojo vizijos ir apoteozès scenų elementus.

Išlikusių Lietuvos benediktinų altorinių atvaizdų ikonografija šv. Benediktą atskleidžia kaip autoritetingą vienuolijos ¡kūrèją ir patriarchą parašyta Regula suformavusi Dievui paskirto autentiško gyvenimo modeli, vyno ir duonos stebuklais liudijusi Dievo artumą akistatoje su neteisybe, mistiškai regejusi visą pasauli, garbingai mirusi ir pakilusi i dangų.

Šis glaustas tyrimas šv. Benedikto ikonografijos temos iki galo neišsemia ir palieka erdvės tolesniems darbams. Už nagrinètos altorinių atvaizdų tipologinès grupès išlieka ne benediktiniškos aplinkos ir naratyvinio pobūdžio kūriniai.

\section{Literatūra ir nuorodos}

${ }^{1}$ Kūrinio nuotraukos publikuotos: Darius Žukauskas, Šventieji Benediktas ir Skolastika, garbinantys Mergele Marija. Šiauliai: Šiaulių vyskupijos ekonomo tarnyba, 2013, p. 18 (paveikslas be aptaisu), 25 (su aptaisais).

${ }^{2}$ Kūrinio nuotrauka publikuota: Aušra Vasiliauskienė, Kauno benediktiniu vienuolyno tyrimai, t. II. Kauno benediktiniu vienuolyno ansamblio menine savastis. Kaunas, Vilnius: Vytauto Didžiojo universitetas, Versus aureus, 2016, p. 68.

${ }^{3}$ Vasiliauskienè, p. 173.

4 Žinomesnius tokio pobūdžio atvaizdus sukūrẻ Antonello da Messina 1475 m. Bažnyčios daktarų su Marija poliptike ir Girolamo Romanino 1515 m. Paduvos Santa Giustina bažnyčios didžiajam altoriui skirtame, keturis šventuosius su Švč. M. Marija perteikusiame paveiksle.

5 Šv. Benediktas atverstą knygą laiko seniausiame šiandien žinomame atvaizde, datuojamame VIII a., jis yra Hermio katakombose Romoje.

6 Vincent Mayr, Benedikt von Nursia, Lexikon der Christlichen Ikonographie. Rom [etc]: Herder 1990, p. 354.

7 Gregor Martin Lechner, Ikonographie des heiligen Ordens vaters Benedikt von Nursia, Benediktinische Kunst. Sud. Roberto Cassanelli et al. IRegensburg: Schnell \& Steiner, 2007, p. 357.

8 Ten pat, p. 365.

9 Marija Matušakaitė, Senoji medžio skulptūra ir dekoratyvine drožyba Lietuvoje. Vilnius: Baltos lankos, 1998, p. 75-76.

10 Vasiliauskienè, p. 68.

11 Lechner, p. 358.

12 Helena Wegner, Benedykt z Nursji. III. Ikonografia, Encyklopedia katolicka, t. II. Lubin: Katolicki Uniwersitet Lubelski, 1976, s. 230.

13 Mayr, p. 354.

14 Gyvatès taurèje nebuvo arba ji neišlikusi.

15 Grigalius Didysis, Šventojo Benedikto gyvenimas. Vertė Jonas Morkus. Vilnius: Aidai, 1996, p. 29.

$161746 \mathrm{~m}$. Vilniaus benediktinių vienuolyno ir bažnyčios vizitacija. ŻVA, A6, 1 .

$171804 \mathrm{~m}$. Vilniaus benediktinių vienuolyno ir bažnyčios vizitacija. ŻVA, A7, 1. 13.

18 Mayr, p. 358.

19 Adalbert de Vogue, Šventasis Benediktas: Dievo Vyras. Kelmè: Palendrių šv. Benedikto vienuolynas, 2011, p. 142.

20 Ten pat, p. 144.

21 Idomu, kad būtent šios vizijos piešinys laikomas vienu labiausiai nepasisekusių Albrechto Diurerio darbų. Roberta J. M. Olson, Jay M. Pasachoff, St. Benedict Sees the Light: Asam's Solar Eclipses as Metaphor, Religion and the Arts 11, 2007, p. 311. 
22 Ten pat, p. 309.

23 Ten pat, p. 302.

24 Ten pat, p. 308.

25 Mayr, p. 359.

26 Kūrinio nuotrauka publikuota: Olson, Pasachoff, p. 312.

27 Kūrinio nuotrauka publikuota: Olson, Pasachoff, p. 313.

28 Kūrinio nuotrauka publikuota: Lietuvos sakraline dailè, t. I. Tapyba, skulptūra, grafika, XIV-XX a. pradžia. Dalia Tarandaitė (sud.). Vilnius: Lietuvos dailès muziejus, 2003, p. 130.

29 Grigalius Didysis, p. 47.

30 Kūrinio nuotrauka publikuota: Lietuvos sakrali$n \dot{e} \ldots$, p. 130.

31 Josefa Oranska, Szymon Czechowicz 1689-1775. Poznan: Nakładem Poznańskiego Towarzystwa Przyjaciół Nauk, 1948, s. 150.

32 Grigalius Didysis, p. 117.

33 Ten pat, p. 117.

34 Kūrinio nuotrauka publikuota: Lietuvos vienuolynai: vadovas. Rūta Janonienè, Dalia Klajumienè (sud.). Vilnius: VDA leidykla, 1998, p. 216.

35 Kūrinio nuotrauka publikuota: Vasiliauskienè, p. 83.

$361799 \mathrm{~m}$. Senujų Trakų benediktinų vienuolyno ir bažnyčios inventorius. VUB RS, f. 57, b. 53, $1122,1.1 \mathrm{v}-2 \mathrm{v}$.

$371820 \mathrm{~m}$. Senujų Trakų benediktinų vienuolyno vizitacija. LVIA, f. 694, ap. 1, b. 4019, 1. 677.

$381830 \mathrm{~m}$. Senujuc Trakų parapinès bažnyčios ir benediktinų vienuolyno vizitacija. LII, f50-p61, 1. 486 .

391919 m. Senųju Trakų parapinès bažnyčios vizitacinis aktas. LVIA, F. 694, ap. 5, b. 5157, 1.7 ir 9.

40 S. Mikulionis, A. Baliulis, Senieji Trakai - piliaviete ir buvęs benediktinų vienuolynas, Lietuvos TSR architektūros klausimai 7(2), 1981, p. 28.

41 Dèl Senujuc Trakų bažnyčios altoriaus paveikslo „Šv. Benediktas" (DV 3225) konservavimo bei restauravimo darbu prièmimo. 199606 18. Aktas nr. 96A-22. Manto Matuizos asmeninis archyvas.
42 A. Snitkuvienè, Raudondvaris. Grafai Tiškevičiai ir ju palikimas. Vilnius: VU, 2001, p. 121.

43 Snitkuvienè dvejoja dèl vietos, mat Čechavičiui priskiriamas paveikslas tebèra Senuosiuose Trakuose ir kelia mintị, kad kūriniai įsigyti iš kažkurio kito benediktinų ar kamaldulių vienuolyno. Janonienè taip pat laikosi šio požiūrio ir bando spejjimą sukonkretini siūlydama Senuju Trakų prepozitūros Pašaltuonyje variantą.

441852 m. Raudondvario bažnyčios statybos dokumentai - inventorius. LVIA, f. 716, ap. 1, b. $205,1.56$.

45 Regimanta Stankevičienè, Benediktinų dailès paveldas Pivašiūnu bažnyčioje, Benediktiškoji tradicija Lietuvoje. Liudas Jovaiša (sud.). Vilnius: Aidai, p. 257.

$461831 \mathrm{~m}$. Pašaltuonio benediktinų bažnyčios ir vienuolyno vizitacija. LVIA, f. 669, a. 2, b. 248, 1.182

$471862 \mathrm{~m}$. Pašaltuonio parapijos bažnyčios inventorius. LVIA, f. 1671 , a. 4, b. 4, 1. 201v.

48 Janonienè, p. 183.

49 Vasiliauskienè, p. 186.

50 Dali kūrinių atlikti Čechavičius patikèdavo savo dirbtuvių mokiniams, tai rodo Vilniaus šv. Kotrynos bažnyčios pavyzdys, kur Čechavičius nutapè pirmojo tarpsnio kūrinius, antrųjų tarpsnių drobes patikèdamas mokiniams.

51 Vasiliauskienè, p. 84-85.

52 MISSALE MONASTICUM PAULI V. PONTIFICIS MAX. AUCTORITATE RECOGNITUM, pro omnibus sub Regula SS. PATRIS BENEDICTI MILITANTIBUS; IN QUO MISSAE SANCTORUM ad normam novi Kalendarii Auctoritate Apostolica approbati ordinate propriis locis dispositae, aliaeque novissimae usque ad hodiernam diem per Summos Pontifices concessae inveniuntur. Venetiis, Apud Nicolaum Pezzana, M DCC LXVIII (1768). Kauno viešoji biblioteka, Retų spaudinių skyrius.

53 Stankevičienè, p. 290; Kūrinio nuotraukos publikuotos: Stankevičienė, p. 272, 291.

54 Ten pat, p. 290.

55 Šv. Benediktas, Šventojo Benedikto regula. Vert. Kęstutis Gražys. Vilnius: Aidai, 1997, p. 113. 